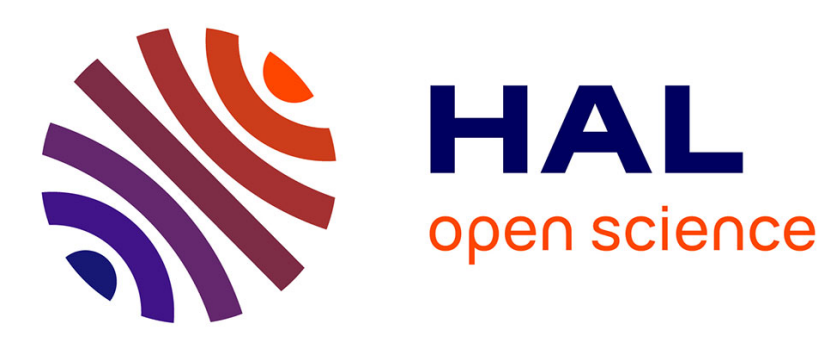

\title{
Ultra-wideband CPW Six-port Circuits Based on Multilayer Technology
}

\author{
Mourad Nedil, Tayeb Denidni, Halim Boutayeb
}

\section{To cite this version:}

Mourad Nedil, Tayeb Denidni, Halim Boutayeb. Ultra-wideband CPW Six-port Circuits Based on Multilayer Technology. Electronics Letters, 2007, pp.vol. 43 no. 23. 10.1049/el:20079380 . hal00189022

\section{HAL Id: hal-00189022 \\ https://hal.science/hal-00189022}

Submitted on 19 Nov 2007

HAL is a multi-disciplinary open access archive for the deposit and dissemination of scientific research documents, whether they are published or not. The documents may come from teaching and research institutions in France or abroad, or from public or private research centers.
L'archive ouverte pluridisciplinaire HAL, est destinée au dépôt et à la diffusion de documents scientifiques de niveau recherche, publiés ou non, émanant des établissements d'enseignement et de recherche français ou étrangers, des laboratoires publics ou privés. 


\section{Ultra-wideband CPW Six-port Circuits Based on Multilayer Technology}

Mourad Nedil and Tayeb A. Denidni and Halim Boutayeb

Abstract: In this paper, a new multilayer six-port circuit using ultra-wideband directional coupler is presented and implemented. The use of the multilayer technology allows having a compact circuit and a very large bandwidth. To validate this concept, a six-port prototype was fabricated and measured. Simulation and measurement results show the proposed six-port circuit can easily operate over an ultra-wide band from 4 to $7 \mathrm{GHz}$.

Introduction: During recent years, there was a great interest in six-port technology due to its broad range of applications. Firstly, the six-port circuit has been well known for its ability to perform accurate low-cost microwave measurements of reflection coefficients of microwave networks [1]. In this area, the six-port circuit was firstly used as a low cost alternative to a vector analyzer. Secondly, the six-port technique was also applied to low-cost communication direct receivers [2, 3], which are less complex and allow a higher integration level compared to conventional heterodyne receivers [4].

Several six-port circuits with various configurations have been presented and examined [5-7]. However, these structures are implemented using a single-layer 
substrate or a waveguide structure, which have a limited bandwidth and a large size.

To resolve these problems, a new two-layer conductor-backed coplanar waveguide (CB-CPW) six-port circuit was designed and fabricated. With this multilayer technology, the proposed design allows achieving high performances in terms of low loss and ultra wideband. In addition, by using a multilayer structure, the proposed six-port circuit allows to avoid cross lines compared to single-layer structures [8]. To demonstrate the performance of the six-port circuit, an experimental prototype was fabricated and measured. The simulation and measured results are presented and discussed in the next sections.

Six-port circuit design: Basically, the six-port circuit is a passive linear device composed of four couplers and a phase shifter. The block diagram of the standard six-port junction is shown in Fig. 1. It has two inputs and four outputs connected at power detectors. The output signals are functions of the two RF input signals. As a result, complex impedance or phase measurements can be obtained by simple power measurements at the four outputs.

Fig. 2 shows the proposed multilayer six-port. This six-port uses four slotcoupled directional couplers [9]. The solid lines show the CPW lines on the top side and broken lines show the $C B-C P W$ lines on the bottom side.

However, in the CB-CPW technology, the main drawback is the parallel-plate modes, which are considered as unwanted bulk modes [10]. The minimum parasitic resonance frequency from the parasitic parallel-plate modes of the CB- 
CPW, which can be predicted, based on a simple rectangular patch theorem [10] as illustrated in the following equation:

$$
f_{m n}=\frac{c}{2 \sqrt{\varepsilon_{r}}} \sqrt{\left(\frac{m}{W_{g}}\right)^{2}+\left(\frac{n}{L_{g}}\right)^{2}}
$$

where $c$ is the velocity of light, $\varepsilon_{r}$ is the relative permittivity, and where $W_{g}(=9$ $\mathrm{mm})$ and $L_{g}(=15 \mathrm{~mm})$ are the width and length of the ground of the coupler as shown in Fig. 1. Using the above equation, the lowest order mode resonance frequency $f_{11}$ of $13.6 \mathrm{GHz}$ is calculated. This parasitic resonance frequency has been shifted to a higher frequency regime. In this case, it can be noted that the leaky wave phenomenon does not affect the performance of the proposed sixport junction, which allows avoiding the use of via in the circuit.

The problem met during the six-port design coupler [9], is related to the fact that the amplitude imbalance is serious between the coupled and direct ports of the six-port structure. The value of the imbalance is up to $3 \mathrm{~dB}$, and this is not appropriate for six-port applications. For this raison, we have reduced the coupling between the direct and coupled port of the coupler to obtain equal power splitting within the passband. With IE3D software, an optimization was carried out to determine the optimal values of the coupler dimensions, which are: $\mathrm{G}=2.8 \mathrm{~mm}, \mathrm{~S}=1 \mathrm{~mm}, \mathrm{~W}=5.5 \mathrm{~mm}$ and $\mathrm{L}=12 \mathrm{~mm}$.

Results and discussion: The six-port junction circuit was fabricated using a Rogers RT/Duroid 5880 substrate with a dielectric constant of $\varepsilon_{r}=2.2$ and a thickness of $h=0.254 \mathrm{~mm}$. Using an HP8722 network analyzer, the S-parameters of the prototype were measured. Fig. 3 shows the simulated and measured S- 
parameters of the proposed six-port junction. It can be noted that the return loss is lower than $25 \mathrm{~dB}$ over the entire operating frequency band $(4-7 \mathrm{GHz})$. It is found that the simulated and measured results are well matched, and the transmission coefficients are close to the theoretical predicted value of $6 \mathrm{~dB}$. From, these results, it can be concluded that the proposed six-port provides a bandwidth from 4 to $7 \mathrm{GHz}(55 \%)$.

Fig. 4 illustrates the simulated and experimental results of the phase shift of the outputs ports, where:

$$
\begin{aligned}
& \text { Phase difference } 1=\text { Phase }(\mathrm{S}(1,3))-\text { Phase }(\mathrm{S}(1,4)) \\
& \text { Phase difference } 2=\operatorname{Phase}(\mathrm{S}(1,7))-\text { Phase }(\mathrm{S}(1,4)) \\
& \text { Phase difference 3= Phase }(\mathrm{S}(1,8))-\operatorname{Phase}(\mathrm{S}(1,7))
\end{aligned}
$$

The phase difference of the output ports over the operating frequency band is close to the simulated ones, which confirm the proposed concept.

Conclusion: In this letter, a multilayer compact CPW six-port circuit has been designed and implemented using broadside CPW slot-coupled couplers. The obtained results show clearly that the two-layer six-port has a reduced size compared to conventional single-layer ones and it provides a very large bandwidth from 4 to $7 \mathrm{GHz}$. The performances in terms of magnitude and phase shift of the proposed six-port are very promising. This six-port has a small volume, light weight, and it ease of fabrication. With these features, the proposed circuit can be used for applications in UWB communication systems.

\section{References}


[1] Tatu, S.O., Wu, K., and Denidni, T.A.: 'Direction-of-arrival estimation method based on six-port technology’ IEE Proceedings Microwaves, Antennas and Propagat. 2006, 3, (153), pp. 263-269.

[2] L. E. hon, RF and Microwave Circuit Design /or Wireless Communications, Boston: Artech House, 1996

[3] Li, I., Bosisio, R. G., Wu, K., 'Computer and Measurement Simulation of a New Digital Receiver Operating Directly Millimeter-Wave Frequencies', IEEE Trans. Microw. Theory Tech., 1995, 12, (43), pp. 2766-2772.

[4] Abe, M., Sasho, N., Brankovic, V., and Krupezevic, D.: 'Direct Conversion Receiver MMIC Based on Six-port Technology', European Microwave Conference Proceedings, section wireless, paris, France, 2000, pp. 139-142.

[5] Tatu, S. O., Moldovan, E., Ke Wu, Bosisio, R.G., and Denidni, T. A.: 'Ka-band analog front-end for software-defined direct conversion receiver,' IEEE Trans. Microw. Theory Tech., 2005, 9,(53), pp. 2768-2776.

[6] Xu, X., Bosisio, R.G., and Wu, K., 'Analysis and implementation of six-port software-defined radio receiver platform', IEEE Trans. Microw. Theory Tech., 2006, 7,(54), pp. 2937-2943.

[7] Zhao, Y., Frigon, J.-F., Wu, K., and Bosisio, R.G.; 'Multi(Six)-port impulse radio for ultra-wideband' IEEE Trans. Microw. Theory Tech., 2006, 4, (54) pp. $1707-1712$.

[8] Akkaraekthalin, P., Sawangnate, C., and Vivek, V.: 'Conductor-backed coplanar waveguide directional coupler and its use for a varactor-tuned $90^{\circ}$ 
phase shifter', IEEE APCCAS 2000 Circuits and Systems, Tianjin, Dec. 2000, pp. 525-528.

[9] Nedil, M., and Denidni, T., A.: 'Quasi-Static analysis of a new wideband directional coupler using CPW multilayer technology', in IEEE, MTT-S Int. Microw. Symp. Dig, San Francisco, USA, June 2006, 1133-1136.

[10] Haydl, W., H.: 'On the Use of Vias in Conductor-Backed Coplanar Circuits', IEEE Trans, on Microwave Theory and Tech., 2002, 6, (50), pp. $1571-1577$.

\section{Authors' affiliations:}

Mourad Nedil, Tayeb A. Denidni and Halim Boutayeb (Université de Québec, INRS-EMT, Place Bonaventure, 800, de La Gauchetière Ouest, bureau 6900, Montréal (Québec), H5A 1K6 
Fig. 1: Block diagram of the proposed six-port junction.

Fig. 2: Layout of the proposed six-port junction

Fig. 3: Scattering parameter of the proposed six-port (a) Simulated (b) Measured.

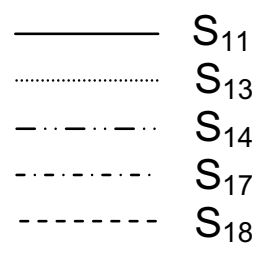

Fig. 4: Phase difference (a) Simulated (b) Measured

$$
\text { Phase(S (1, 3)) - Phase }(S(1,4))
$$

-..... Phase(S $(1,7))$ - Phase(S $(1,4))$

Phase(S $(1,8))$ - Phase $(S(1,7))$ 


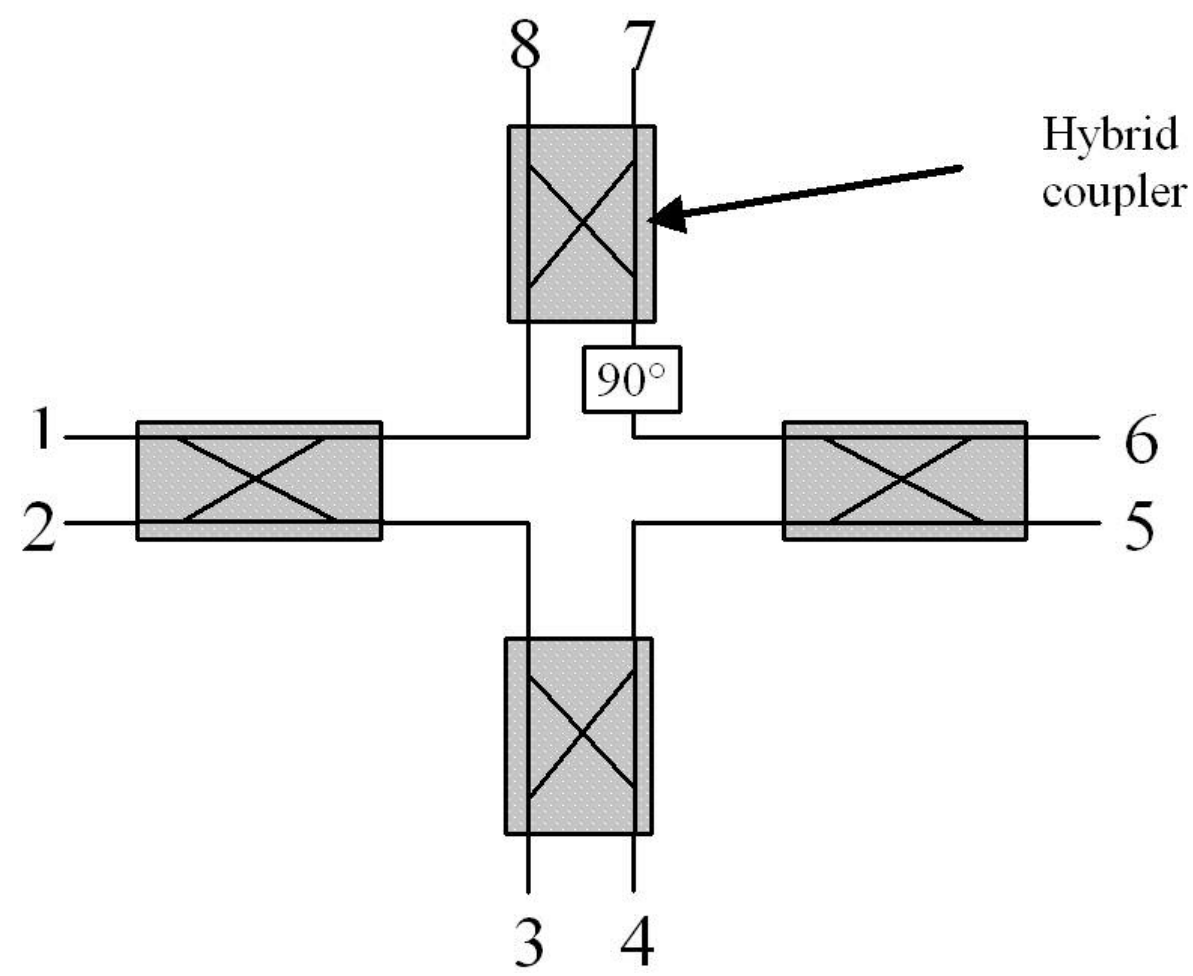

Fig. 1: Block diagram of the proposed six-port junction.

$73 \times 54 \mathrm{~mm}(300 \times 300 \mathrm{DPI})$ 


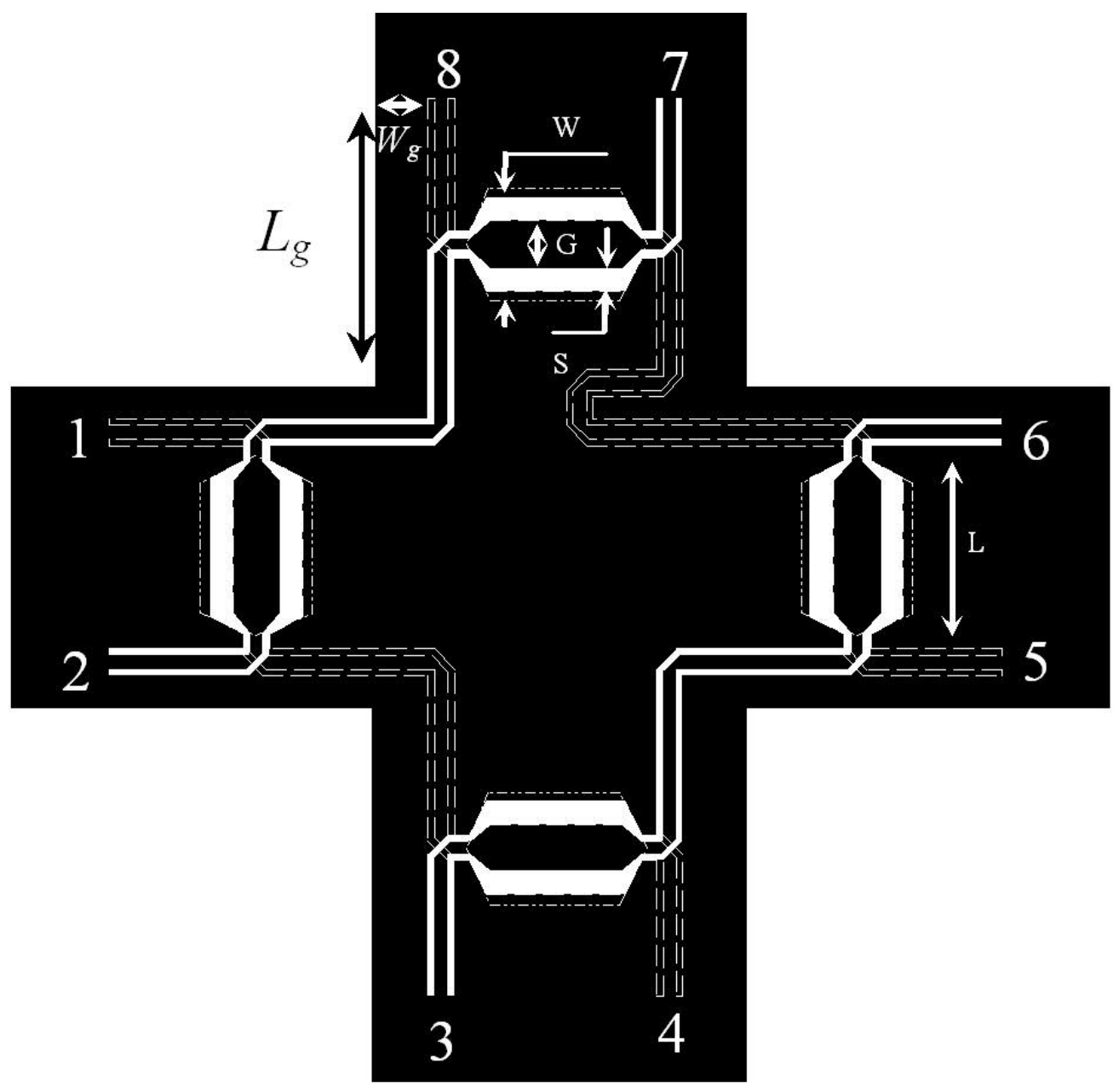

Fig. 2: Layout of the proposed six-port junction. $79 \times 76 \mathrm{~mm}(300 \times 300 \mathrm{DPI})$ 


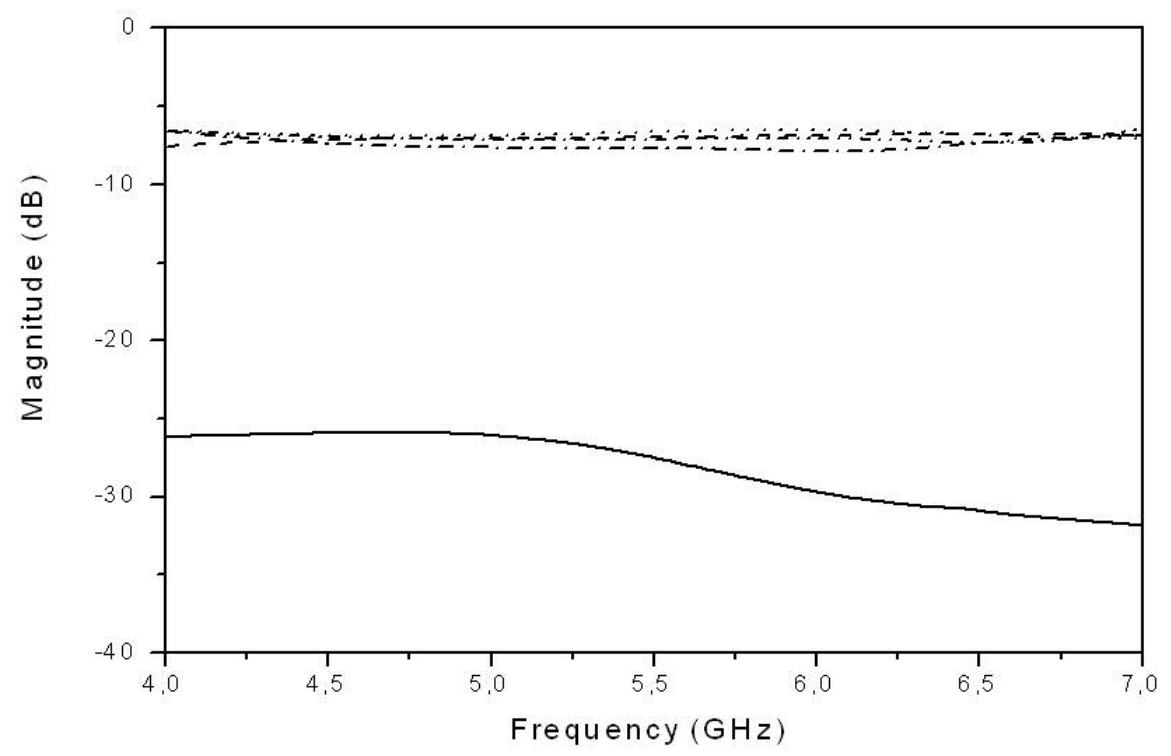

Fig. 3: Scattering parameter of the proposed six-port (a) Simulated. $78 \times 51 \mathrm{~mm}(300 \times 300$ DPI $)$ 


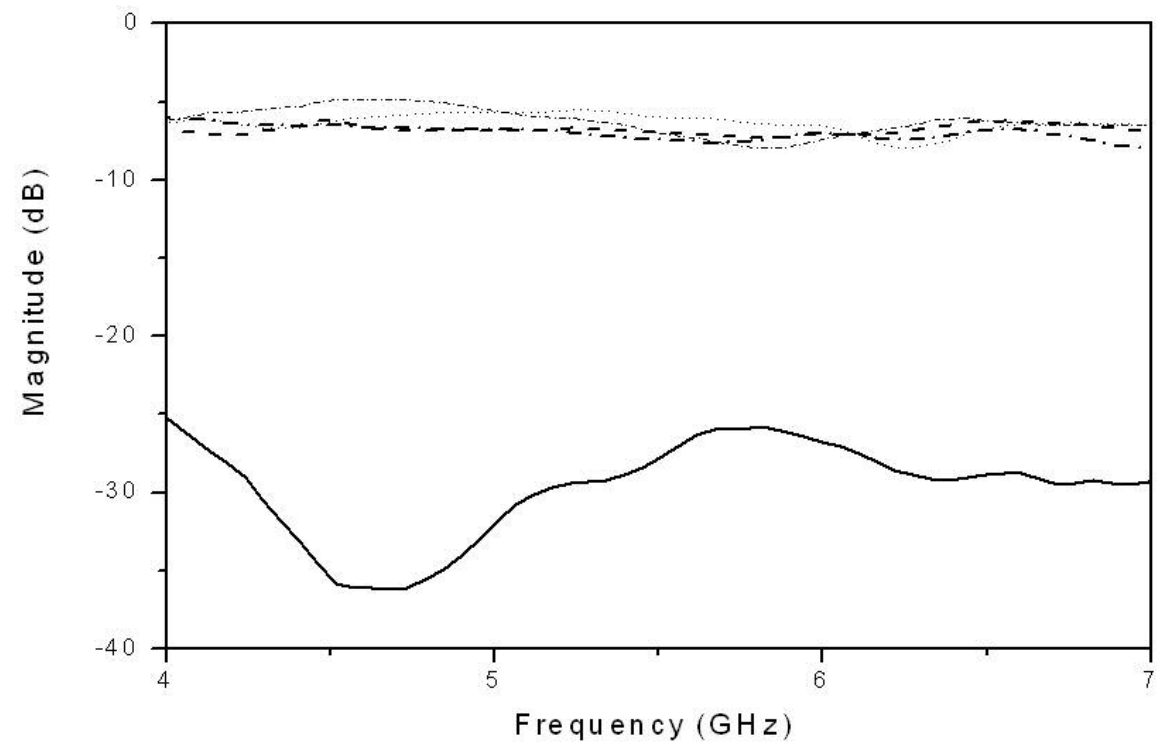

Fig. 3: Scattering parameter of the proposed six-port (b) Measured. $77 \times 51 \mathrm{~mm}(300 \times 300$ DPI $)$ 


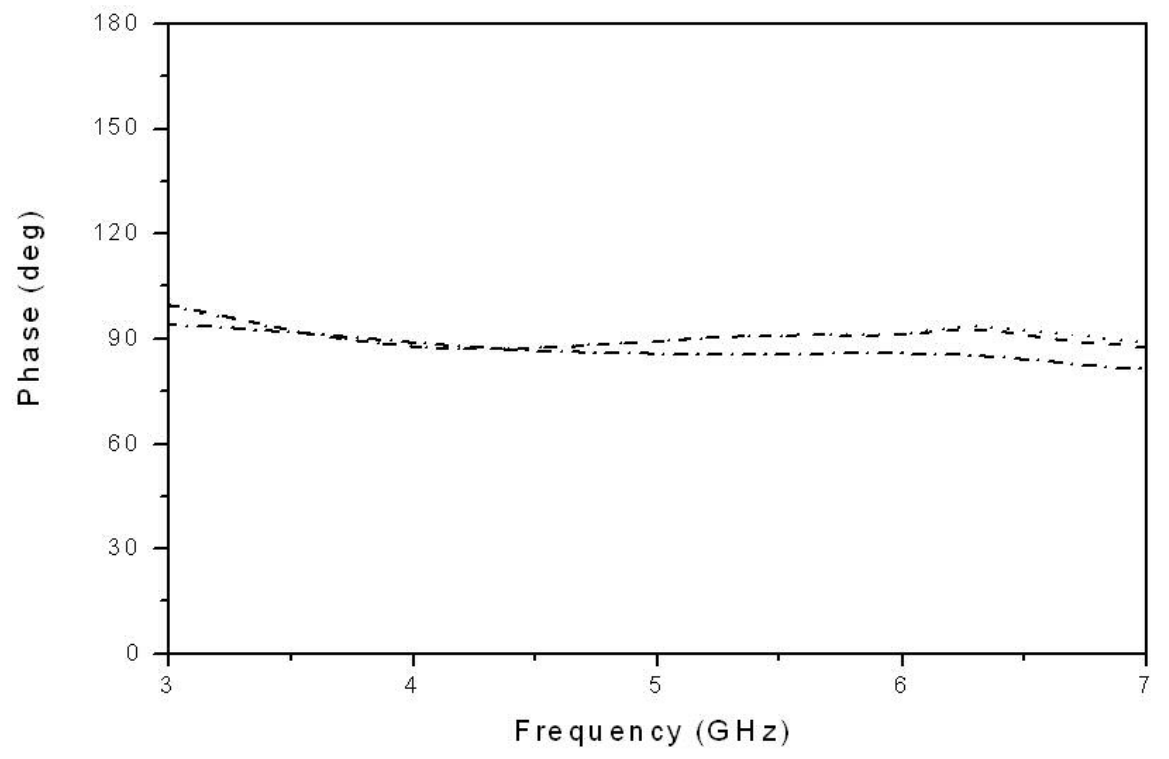

Fig. 4: Phase difference (a) Simulated. $78 \times 52 \mathrm{~mm}(300 \times 300$ DPI $)$ 


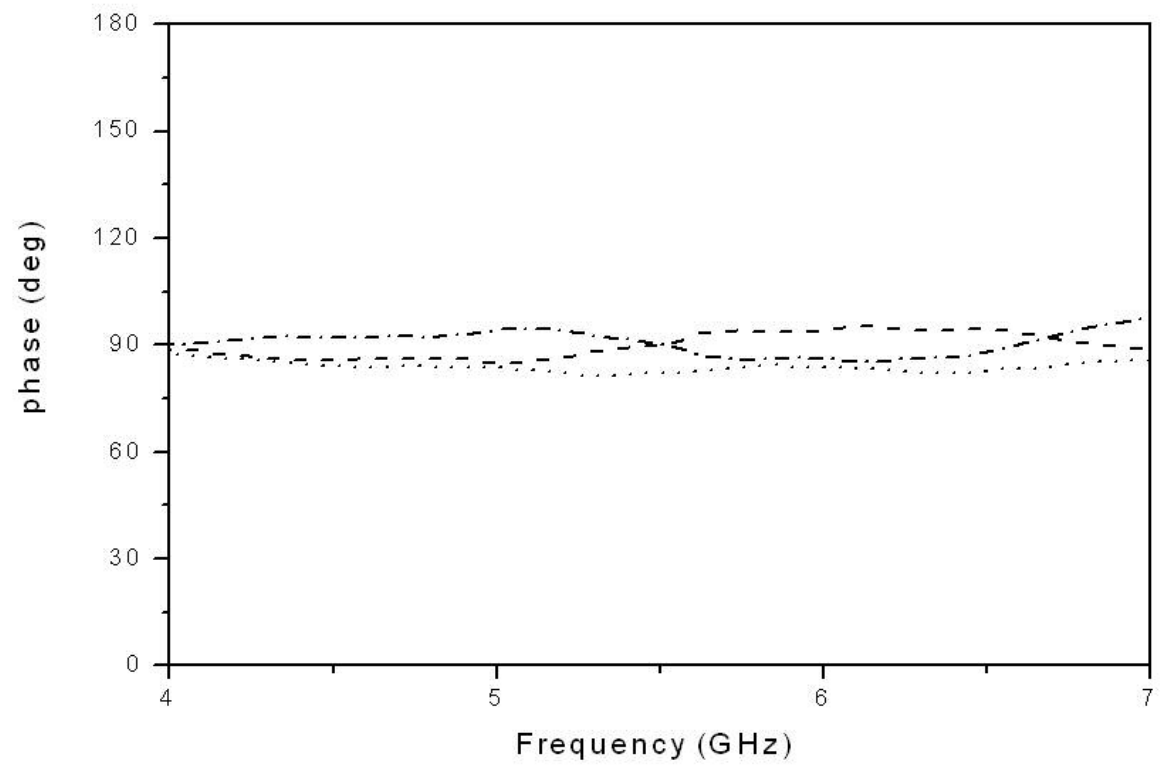

Fig. 4: Phase difference (b) Measured.

$77 \times 52 \mathrm{~mm}$ (300 x 300 DPI) 